\title{
新苛性化設備の操業経験*
}

紀州製紙株式会社 紀州工場 堀 口誠

\section{Operating Experience of Our New Recausticizing System}

Makoto Horiguchi

Kishu Mill, Kishu Paper Co., Ltd

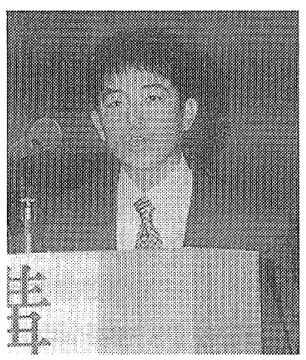

In May 1999, new recausticizing system and Lime kiln started at Kishu Paper Co., Ltd Kishu Mill.

This recausticizing system consists of mainly PD-filter for white liquor, Lime mud filter and Lime reburning kiln with flash dryer.

Now we report the operating experience and some troubles of new recausticizing system.

分類： $F_{3} K P$ 黑液回収 ·製薬, $W_{1}$ 蒸解薬品

1.はじめに

当工場前性化設借は，旧設備の老朽化及び省口スを 目的として, 石灰焼成設備及び白液処理設備を更新し た。今回は，新たに導入したライムキルン，加圧ディ スクフィルター $(\mathrm{PDF})$, ライムマッドフィルターを 中心に, 新苛性化設備の操業経験について紹介する。

\section{2. 導入の経緯}

従来の苛性化工程は, 緑液処理設備 1 系列, 白液処 理は 2 系列，石死焼成設備は，メインにライムキルン， ライムキルンの処理能力不足を補う為にカルサイナー (石灰泥流動か焼設備)の間久運転という变則的な工 程となっていた。

設備更新は，カルサイナー間久運転によりロスの大 きい石灰焼成設備及び老朽化の進んでいる白液クラリ ファイヤー（沈降分離型清澄槽）の更新をメインに実 施した。石灰焼成設備は, ランニングコストの低い FL スミス社のフラッシュドライヤー付きライムキルンを

*平成 11 年度年次大会講演（講演 No. B 3)
採用, 白液処理には，白液品質向上（SS 濃度の低減） と設置スペースの制約からクラリファイヤー採用は見 送り，PDFを採用した（写真 1)。

\section{3. 工程の概要}

概略フローを図 1 に示す。ライムマッドウォッシャ 一は従来 2 段タイプをシリーズで 2 基使用していたが, PDFの採用により持ち込みアルカリ量の減少が予想

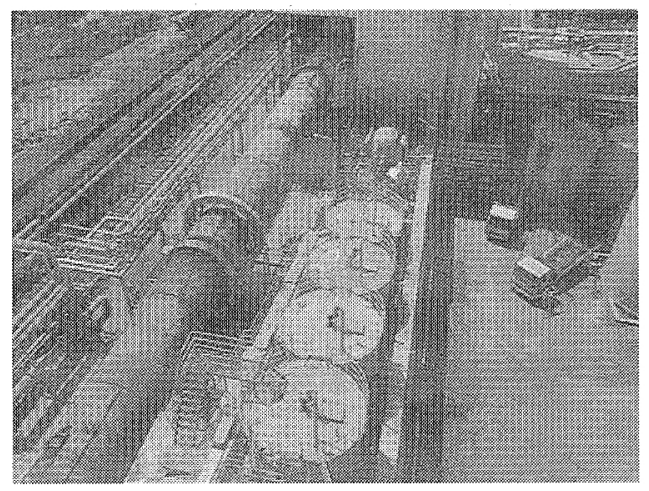

写真 1 新苛性化設備 


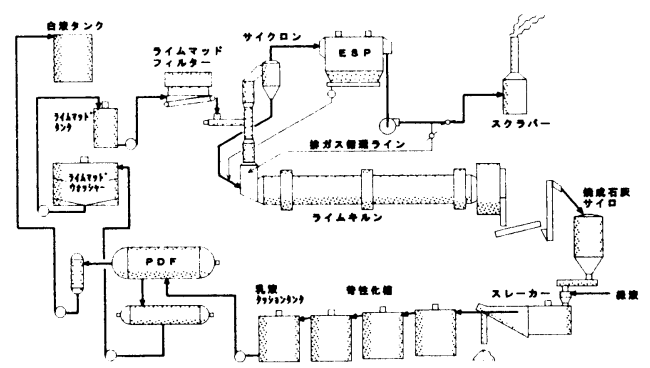

図 1 新䒬性化設備概略フロー

されたため，当面 1 基のみ使用することとした。また， 苛性化槽は将来の増産を見越した容㫣を持たせており， 現在の処理量では 1 基バイパスしても連転可能である が, ショートパスの叮能性もゼロではないので苛性化 反㐫が光全に終〕した状態でPDFに供給すべく 3 基 とも使用している。電父集㦄機（ESP）で捕集された ダストは、食削キルンに闪しているが現在のところ問 題は発牛していない。

\section{4. 設備の概要}

・スレーカー $\phi 4,500 \times 2,900$

- 䓶性化槽 $\phi 4,500 \times 6,5002$ 槽式 3 基

- PDF

$\phi 2,800 \times 4,500$ (㽢婀激)

ディスク：6枚

们液牛座星：2, $100 \mathrm{~m}^{3}$ 川

・ライムマッドフィルター

$\phi 3,600 \times 5,000$

プレコート速続史新装管付

・ライムキルン

$\phi 3,000 \times 60,000$

フラッシュドライヤー付

牛産量：180 T \| as product

・コンパックスクーラー

$\phi 6,000 \times 2,400$

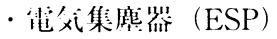

$850 \mathrm{~m}^{\prime \prime} \min 2$ 犁

- ID ファン

$910 \mathrm{~m}^{3} \min$

・スクラバー

スプレートレイ型

胡装類

・酸素濃度部

ESP出にに設置
・一酸化炭素濃度計

ESP 出口に設置

・バーナーチップ温度計

重油バーナー先端部に設置。熱電対。

・キルンシェルスキャナー

LAND 社製。ホットスポット，ダムリング生成 状況のモニターとして使用。

・アルカリ自動分析計

プロチェック社製。旧設備から移設。

\section{5. 操業状況と各設備の特長}

平成 11 年 4 月より, PDF の操業を開始，キルン及 び苛性化については 5 月から操業を開始した。現在の 白液所要量が設計仕様の $2,100 \mathrm{~m}^{3}$ 日に満たないため, 設備什様的には余裕のある状態となっている。

5.1 スレーカー

スレーカーでの制御方法は, 石灰投入量による緑液 とスレーカーとの温度差コントロールまたはスレーカ 一温度のコントロールのどちらかを選択出来る（図 2）。 現在はスレーカー温度コントロールを選択して状況を 見ている。スレーカーの温度設定はオペレーターが行 っているが, 処理量に応じて変更するほか, アルカリ 白動分析装置での分析結果をみて変更している。クラ リファイヤーから PDFへの変更により，オーバーラ イム等に関してはよりシビアな監視が必要となってい る。スレーカーでの制御状況を図 3 に示す。

スレーカーの排気は $Z$ 型のスクラバーを経て大気 放出されるが，旧設備でみられた排気筒の閉塞は発生

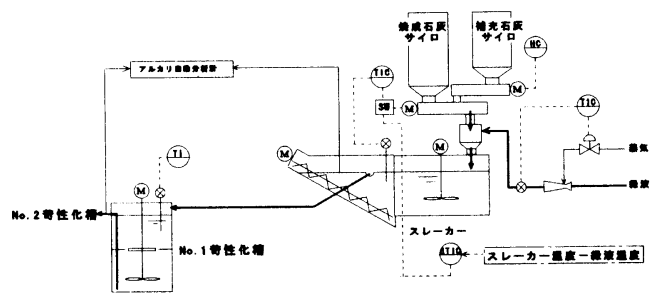

図 2 スレーカー温度コントロール

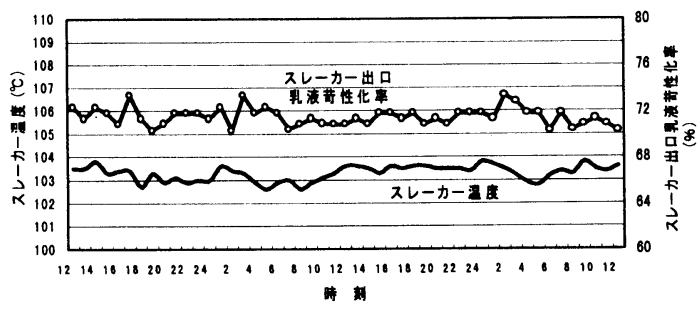

図 3 スレーカー制御状況 
していない。スクラバーシャワーのオーバーフローの SS が低いことから，ダストの発生も抑えられている と考えられる。

スケールの付着状況は，運転開始後約 3 ケ月の夏期 定期修理時に内部点検を行った結果，側壁，スクリュ 一等に約 $7 \mathrm{~mm}$ 程度の付着が見られた。

\section{2 PDF}

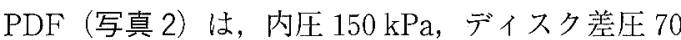
$\sim 90 \mathrm{kPa}$ の設定で操業している。プレコート層更新 は，ノックオフシャワー洗浄により実施しており，エ アーブロータイプと比較してシャフトの構造が簡単で ある。ノックオフ洗浄は，通常 6 8 時間に 1 回実施 している。ただし，ろ布の目詰まりが進行し，ノック オフ洗浄でも再生しない場合には酸洗浄が必要となる。 稼働後約 2 ケ月目に酸洗浄を実施した。また，乳液の 性状によってはろ過性が悪化するため, 乳液苛性化率 を適正範囲に維持する必要がある。

ろ過性能は，万布が正常な場合にはSSが $10 \mathrm{mg} / l$ 以下と良好な值を示すが，運転開始直後万布に初期不 良と思われる破孔があり，SSの上昇を経験した。破 孔した場合にはSSが急激に上昇するため，迅速な対 応が必要である。

PDF では，オーバーライミングによるろ過不良を 経験している。このオーバーライミングは長期停止後 の立ち上げ時に経験したものであるが，万過不良とな った場合には，通常 6〜8 時間每のノックオフ洗浄の インターバルが 15 分程度となるため, 正常な乳液が 供給されるまで処理を落とし，ノックオフ洗浄を頻繁 に実施して対処した。

\section{3 ライムマッドフィルター}

ライムマッドフィルターは，連続プレコート更新装 置（スカート）を装備して抢り，従来よりもライムマ ッド水分の変動が少ないドラム型バキュームフィルタ

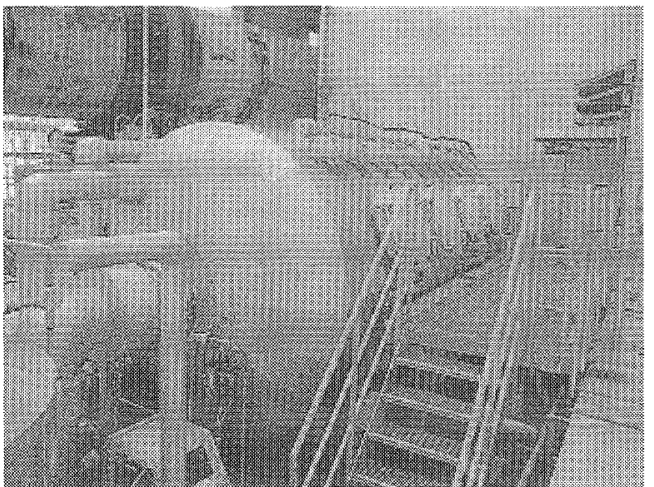

写真 2 PDF
一である。スカートは，移動式シャワーヘッドと，高 圧シャワーポンプにより構成され，プレコート層を連 続的に更新するものであり，キルンへのライムマッド 供給の安定化に大きく寄与している（写真 3）。

操業開始当初，シャワーノズルの移動速度設定を往 復 2 時間としていたが，フィルタードラムの軸方向で 水分差が大きく，キルンフラッシュドライヤーでの温 度変動が, サイクロン出口で約 $50^{\circ} \mathrm{C}$ 見られた。現在 は、シャワーノズルの移動速度設定を往復 40 分とし て水分の变動を抑えている（図 4)。

\section{4 ライムキルン}

FL スミス社のフラッシュドライヤー付きライムキ ルンの特長として,

・排ガス循環システム

・キルン供給側端部のシンプルな構造

・熱回収効率の高いコンパックスクーラー が挙げられる。

\subsection{1 フラッシュドライヤー}

今回採用された新型フラッシュドライヤーは排ガス 循環システムを備えており, 従来型のようなフラッシ ュドライヤー部のダンパーは不要となっている。燃焼 状態の変動や石灰焼成量の変更に応じて排ガス循環量 を調節することによって，ライムマッド供給部でのガ 又流速を維持し，排ガス中の酸素濃度を最適にキープ する事が可能である。フラッシュドライヤーで乾燥さ れたライムは，スモークチャンバー下部の傾斜を滑っ

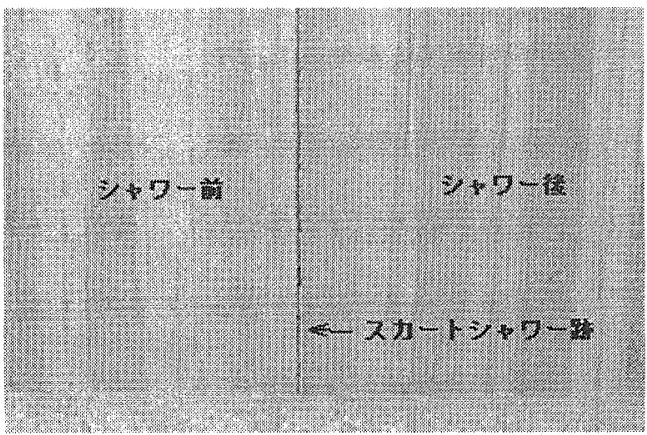

写真 3 ライムマッドフィルター表面

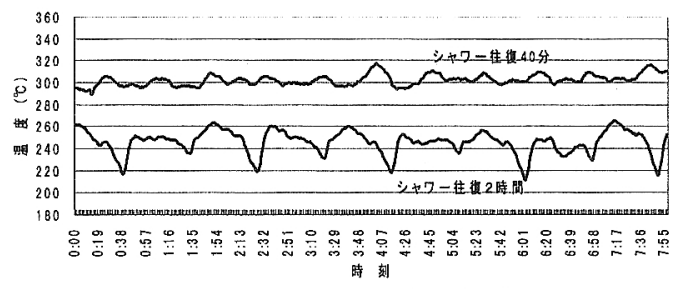

図 4 サイクロン出口温度 
てキルンに供給されるため，ライムを掻き上げるスコ ップ等を持たないシンプルな構造となっている（写真 4)。導入時には傾斜部でのライム堆積が懸念されたが,

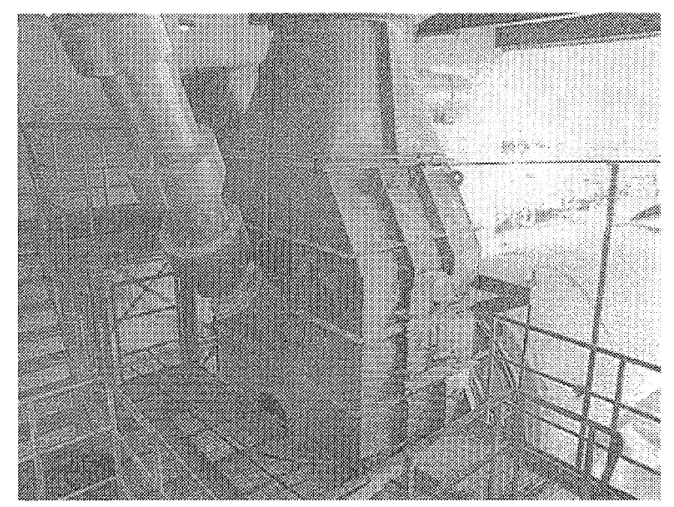

写真 4 スモータチャンバー

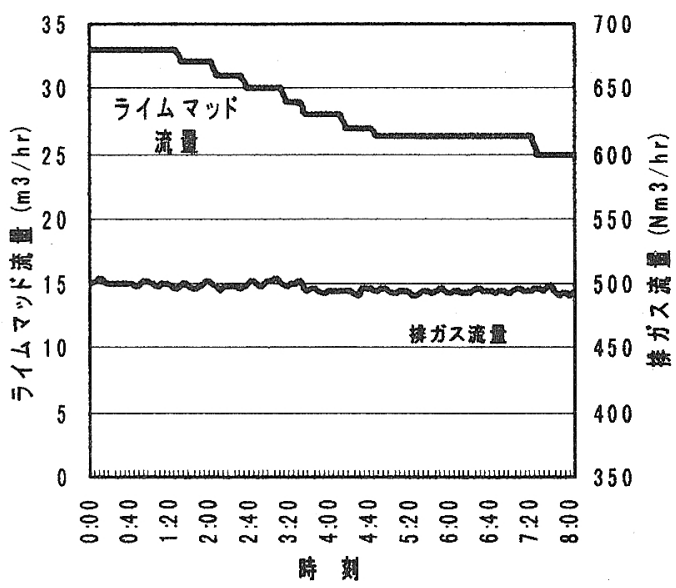

図 5 排ガス制御状沉(1)

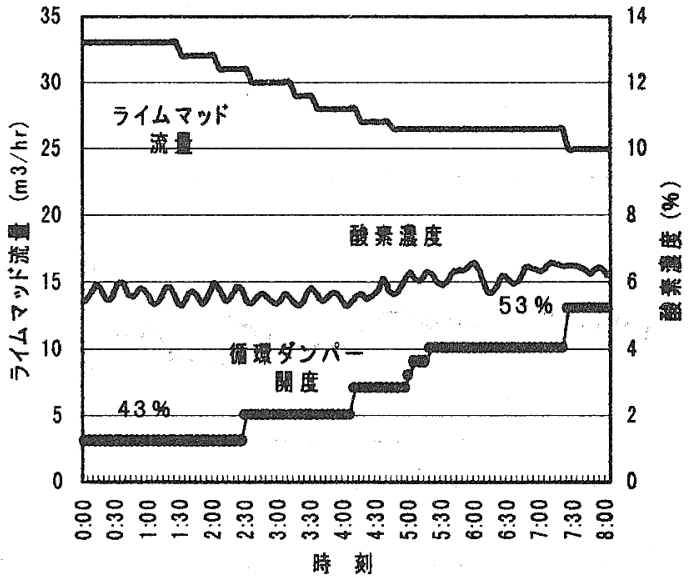

図 6 排ガス制御状況(2)
スムーズに流れているようであり，現在のところライ 么の堆積は見られない。但し，現在は点検も兼ねて8 時間に 1 回程度エアーランシングを実施している。

石灰焼成量変更時の排ガス制御状況を図 5 , 図 6 に 示す。キルンシェルとスモークチャンバーとのシール 面には連続給脂装置によりグリスが給脂されており， 現在のところダストの飛散も無く良好な状況である。

5.4 .2 キルン本体

キルンシェルはキルンスキャナーで温度を測定し, レンガ脱落, ダムリングの生成状沉を監視している(図 7)。運転開始約 3 ケ月後に夏期定期修理を迎元, 内部 点検を実施した。スキャナーの測定結果から予想され たようにダムリングは付着しており，ダムリング生成 状況の監視に有効である。但し，スキャニング範囲は No.2夕イヤから弿尻側としており, 今後は燃焼ゾー ンでの監視も必要と考えている（図 8)。

キルンの落口にはノーズリングとよばれる金物が全 周に取り付けられており，脱落したダムリング等の大 塊はここで砕かれ，コンパックスクーラーに送られる。 現在まで，ノーズリングでの大塊の詰まり等は見られ ず，大塊の破砕効果は大きいようである。

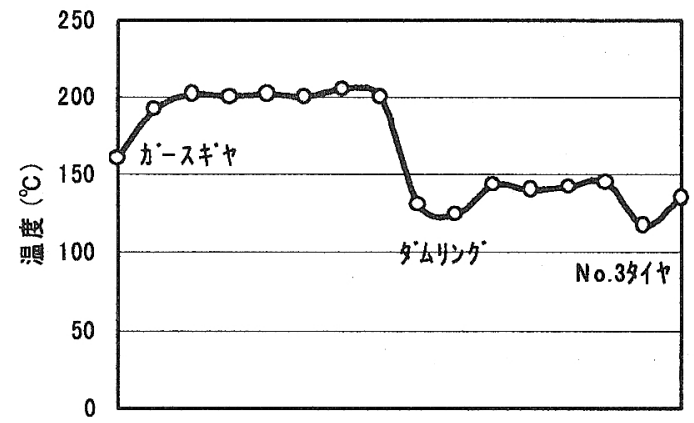

図 7 キルンシェル温度

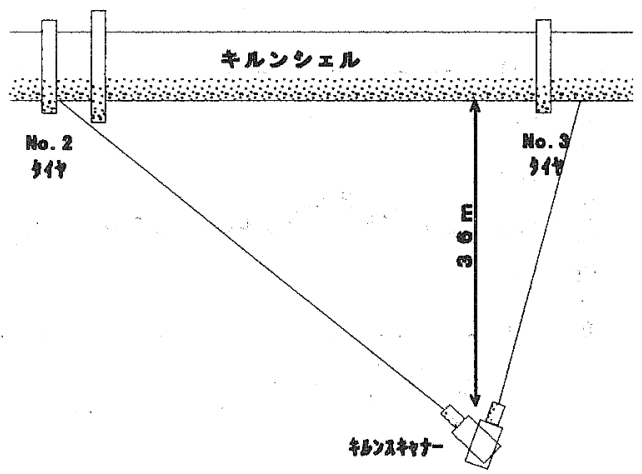

図 8 キルンスキャナー設置概要 


\subsubsection{ESP}

今回キルン排ガスダスト処理には環境面への配慮か ら，電気集塵機（ESP）とスクラバーをシリーズで採 用した。排ガス中のダスト測定值を見ても集塵性能に 問題は無い。ESPでは，操業開始後的 2 ケに，下 部の傾斜板に堆積した大量のダストの脱落によると考 えられる，スクリューコンベアのトリップが発生した。 この件については，傾斜板へのバイブレーター取付を 計画している。

\subsection{4 コンパックスクーラー}

焼成石灰は， $\phi 6 \mathrm{~m} \times 2.4 \mathrm{~m}$ のコンパックスクーラ 一で 2 次空気と熱交換され，コンベアを経てサイロに

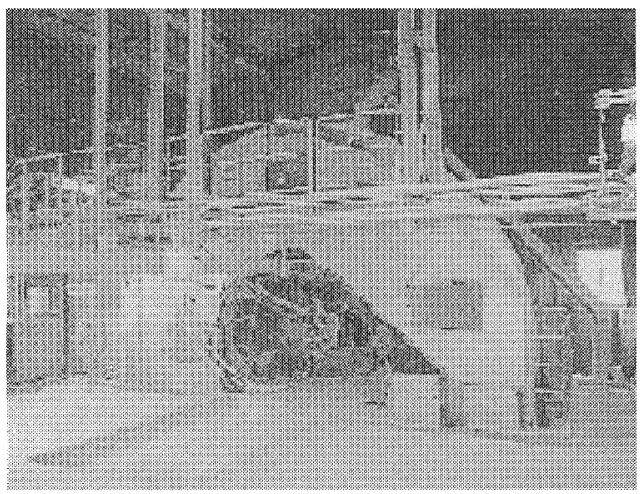

写真 5 コンパックスクーラー 送られる。従来のサテライトクーラーと違い, キルン シェルを覆う構造ではないため，キルンシエル全面の 監視が可能であり，焼成石灰からの熱回収効率も向上 している。コンパックスクーラーでの閉塞等が懸念さ れたが，スケーリングや大塊の詰まりは発生していな い(写真 5)。

\section{6. 性能保証值と実績}

処理量を上げての性能確認テストは未実施のため, 参考值として現在までの害績を示す（表 1)。

キルンの然料消費量については，今後のメンテナン スを考慮して FL スミス指定の輸入レンガではなく,

表 1

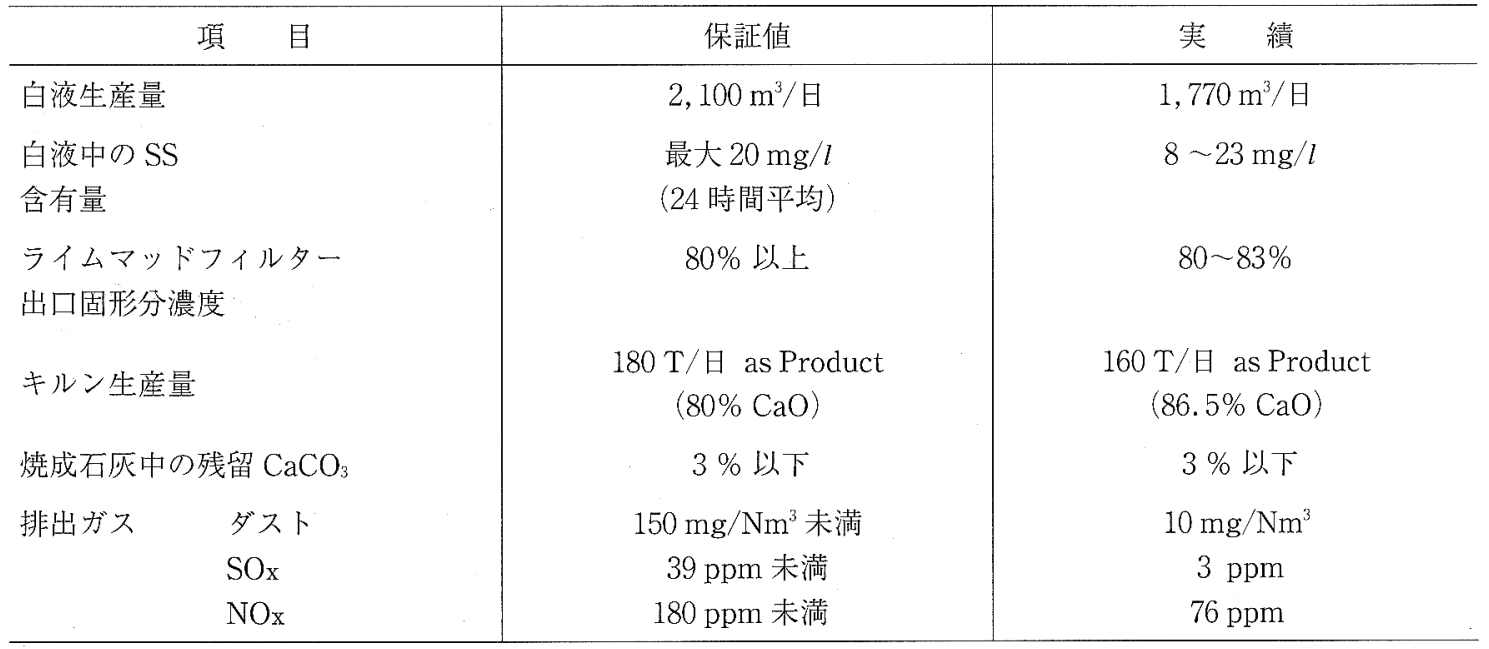

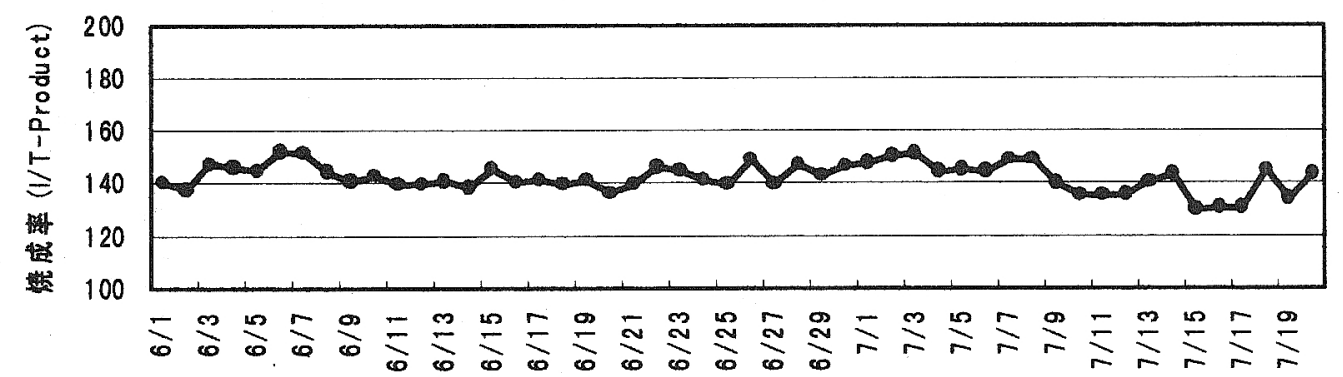

間 $\mathrm{H} 11.6 .1 \sim 7 / 22$

図 9 焼成率 (燃費) 推移 
国産レンガを使用したため保証範囲外となっている が, $150 l \mathrm{~T}$-product の設計仕様に対して, 現在迄の ところ平均すると約 $140 l \mathrm{~T}$-product と良好な值を示 している(図9)。

7. おわりに

新苛性化設備稼動後, 各設備に少なからずトラブル が発生したが, 大略順調に稼働している。しかし, キ
ルンダムリングのように未解決のものもあり, 操業の 安定化のために苛性化全体の運転方法の見直しが必要 である。今後の計画として, 苛性化及びキルンへのフ アジー制御の導入と緑液クラリファイヤーの更新を計 画している。

最後にこの新苛性化設備更新にご尽力頂いたクヴァ ナパルピング株はじめ関係各社各位にこの場を择借し て，深く御礼申し上げます。 